\title{
PERFORMANCE ASSESSMENT METHOD OF URBAN WASTE MANAGEMENT SYSTEMS FROM NEAMŢ COUNTY, ROMANIA
}

\section{Florin-Constantin Mihai ${ }^{1}$}

Key words: P.A.M., waste management, urban areas, disparities

\begin{abstract}
This paper proposes a performance assessment method (PAM) at urban scale, based on five specific waste indicators such as: population access to waste collection services (\%), separate collection (\%), reuse \& recycle (\%), landfilling (\%) and amounts of waste uncollected (Qwu-\%). Values of each indicator are correlated to an assessment table for three different years $(2004,2007,2010)$ highlighting the disparities between urban localities from Neamț County. The paper also examines the changes and dysfunctions of urban waste management systems between preaccession vs post-accession period. PAM should be a necessary tool for environmental authorities or decision-makers for monitoring process of municipal solid waste systems from various cities on regional scale particularly for new EU members.
\end{abstract}

\section{Introduction}

Urban waste management system from new EU countries is facing real challenges in providing proper waste management services according to waste hierarchy concept. Major disparities are reflected in current municipal waste management system between and within continents (Karak et. al., 2012; Mihai and Apostol, 2012). Each state develops waste indicators in order to assess the improvement of this sector at national or regional scale (Cifrian et al., 2012; Passsarini et al, 2011; Desmond, 2006).

These waste indicators should be chosen for a proper multi-scale analysis. Also an improvement of data from local authorities and waste operators should be constantly performed in order to reflect the real situation in the field.

The paper develops a performance assessment method (PAM) of municipal waste management based on such indicators which can be applied on local or regional scale providing a necessary tool for monitoring this sector at urban level.

\footnotetext{
${ }^{1}$ Ph.D. stud. ”Alexandru Ioan Cuza”University, mihai.florin86@ yahoo.com
} 


\section{Materials and methods}

The paper selected five waste indicators in order to assess the performance of a urban waste management system. This is a necessary tool for comparative analysis between several cities on local or regional scale. These indicators are:

$\checkmark$ population access to waste collection services (\%),

$\checkmark$ separate collection (\%) including five recyclable fractions such as paper/cardboard, plastic, metal, glass, wood and also the biodegradable fraction which may be used as compost.

$\checkmark$ reuse \& recycle $(2 \mathrm{R}-\%)$,

$\checkmark$ landfilling (\%),

$\checkmark$ amounts of waste uncollected (Qwu-\%).

These indicators are calculated for every urban locality based on information provided by EPA Neamț, local authorities or waste operators. Also, these indicators are calculated for 2004 (pre-accession period when traditional waste management system prevailed for all cities), 2007 (year of EU accession), 2010 (post-accession period reflecting the transition from a traditional to an integrated waste management system). Each indicator according to its percentage values will get a score which will be added to the total amount of points accumulated by an urban waste management system.

Tab.1. Assessment table of household and similar waste indicators

\begin{tabular}{|c|c|c|c|c|c|c|c|c|c|}
\hline \multicolumn{2}{|c|}{ WCS (\%) } & \multicolumn{2}{c|}{ SC } & \multicolumn{2}{c|}{ 2R } & \multicolumn{2}{c|}{ Landfilling } & \multicolumn{2}{c|}{$\mathbf{Q}_{\mathbf{w u}}$} \\
\hline$\%$ & Score & $\%$ & Score & $\%$ & Score & $\%$ & Score & $\%$ & Score \\
\hline$>90$ & 10 & $>80$ & 10 & $>60$ & 10 & $>90$ & 0 & $>20$ & 0 \\
\hline $80-90$ & 8 & $60-80$ & 8 & $40-60$ & 8 & $70-90$ & 2 & $15-20$ & 2 \\
\hline $70-80$ & 6 & $40-60$ & 6 & $20-40$ & 6 & $60-70$ & 4 & $10-15$ & 4 \\
\hline $60-70$ & 4 & $20-40$ & 4 & $10-20$ & 4 & $40-60$ & 6 & $5-10$ & 6 \\
\hline $50-60$ & 2 & $10-20$ & 2 & $5-10$ & 2 & $20-40$ & 8 & $2-5$ & 8 \\
\hline$<50$ & 0 & $<10$ & 0 & $<5$ & 0 & $<20$ & 10 & $<2$ & 10 \\
\hline
\end{tabular}

These indicators are used according to the waste hierarchy principle, thus, high values of some indicators that promote these principle such as waste collection services, separate collection (SC), reuse \& recycling (2R) correspond to a higher score. On the other side, high values of some indicators which correspond to a traditional waste management system such as landfilling or $\mathrm{Q}_{\mathrm{wu}}$ will get fewer points. Also, these percentage values are specific to each indicator and cannot be uniform, these are selected in order to express more accurately the positive or negative implications for an urban waste management system.

Finally, based on total score, each municipal waste management system corresponds to a certain category such as: excellent (45-50 max.), good or 
efficient (35-45), moderate or proper (25-35), inefficient (20-25), poor ( 10-20), rudimentary or lacking $(<10)$.

\section{Results and discussion}

The share of urban waste collection services (WCS \%) is a relevant indicator for studying an urban waste management system in Romania because these services still do not cover the entire population, favoring illegal dumping of household waste. Furthermore, Mihai et al. (2012) and Mihai (2012) highlight the major disparities between Romanian counties regarding the urban population access to WCS. Also, these disparities are reflected at local scale between urban localities from Neamţ County.

Tab.1 Population access to waste collection services (\%)

\begin{tabular}{|cccc|}
\hline WCS (\%) & $\mathbf{2 0 0 4}$ & $\mathbf{2 0 0 7}$ & $\mathbf{2 0 1 0}$ \\
Piatra Neamţ & 60.8 & 62.91 & 64.72 \\
Roman & 70.79 & 78.54 & 81.83 \\
Tirgu Neamţ & 42.14 & 42.32 & 47.34 \\
Bicaz & 64.22 & 50.2 & 76.7 \\
\hline
\end{tabular}

Data source: processing data from EPA Neamt, waste operators

According to table 1, no urban locality from the county has a higher value than $85 \%$ of WCS in the 2004-2010 period. Major differences between Roman and others towns is due to rural localities included in administrative territorial units (ATU) of urban areas which are not served by WCS. Also the private sector of WCS has developed earlier in Roman and Piatra Neamţ (including significant investments) than Bicaz or Târgu Neamţ. Roznov has no WCS until 2011, since a separate collection is implemented and a transfer station is operational.

Tab. 2. Share of SC (\%) from total amounts of household and similar waste (HSW)

\begin{tabular}{|cccc|}
\hline SC (\%) & $\mathbf{2 0 0 4}$ & $\mathbf{2 0 0 7}$ & $\mathbf{2 0 1 0}$ \\
Piatra Neamţ & 0.12 & 38.09 & 38.36 \\
Roman & 0.092 & 1.06 & 1.28 \\
Tirgu Neamţ & $\mathbf{0}$ & $\mathbf{0}$ & $\mathbf{0}$ \\
Bicaz & $\mathbf{0}$ & $\mathbf{0}$ & $\mathbf{0}$ \\
\hline
\end{tabular}

Data source: processing data from EPA Neamt, waste operators 
Mixed waste collection prevailed during 2004-2010 in Târgu Neamţ and Bicaz $(\mathrm{SC}=0)$, separate collection being provided since 2011. Also, separate collection systems were in early stages in 2004 for Piatra Neamţ and Roman.

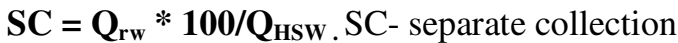

$\mathbf{Q}_{\text {HSw }}=$ household and similar waste collected

$\mathbf{Q}_{\mathbf{r w}}=$ recyclable waste collected 5+1, (t/yr), total sum of paper/cardboard, plastic, metal, glass, wood and biodegradable waste, these fraction are collected from special containers.

Separate collection is insignificant in Roman during 2004-2010 because there was no facility for recycling, treatment or composting municipal waste. On the other side, Piatra Neamt has extended the separate collection systems in every collection point of the town since 2007, reflecting the higher values compared to 2004.

Tab. 3. Share of $2 \mathrm{R}(\%)$ from total amounts of HSW collected

\begin{tabular}{|cccc|}
\hline P\% 2R & $\mathbf{2 0 0 4}$ & $\mathbf{2 0 0 7}$ & $\mathbf{2 0 1 0}$ \\
Piatra Neamţ & 0.037 & 9.33 & 3.86 \\
Roman & 0.085 & 0.088 & 0.248 \\
Tirgu Neamţ & $\mathbf{0}$ & $\mathbf{0}$ & $\mathbf{0}$ \\
Bicaz & $\mathbf{0}$ & $\mathbf{0}$ & $\mathbf{0}$ \\
\hline
\end{tabular}

Piatra Neamţ has an operational sorting and composting stations (2007) which reflect higher values of $2 \mathrm{R}$ compared to 2004 , yet the maximum values are still under $10 \%$. This fact highlights the early stages of the integrated urban waste management system implemented through ISPA funds.

Most of the Romanian towns are facing the transition period from mixed waste collection and landfilling (traditional way) to reduce, reuse and recycling (3R policy) specific to an modern waste management system.

The poor values of the $2 \mathrm{R}$ indicator outline the fact the main current option in municipal waste management is still landfilling (over $90 \%$ for every town of the county during 2007-2010). Thus, according to the assessment table (Tab. 1) the score of this indicator is 0 for all towns in every year.

Furthermore, municipal waste (beside HSW fraction is also included garden \& street waste, construction \& demolition waste) is disposed in non-compliant landfills which are often located on improper sites close to the residential areas (Mihai et al., 2012). Piatra Neamţ has a sanitary landfill (2 cells) which serves only this municipality until 2017. 
The last indicator used for PAM refers to the uncollected waste $\left(\mathrm{Q}_{\mathrm{wu}}\right)$. Mihai et al. (2011) outlined the vulnerability to illegal dumping of urban areas from Romanian counties using this indicator. In order to highlight this vulnerability at local scale it is calculated for every city applying the following formula:

$\mathbf{Q}_{\mathrm{wu}} \mathbf{t} / \mathbf{y r}=\mathbf{P}_{\mathrm{u}} * \mathbf{I}_{\mathrm{g}} * \mathbf{3 6 5} / \mathbf{1 0 0 0}, \mathbf{P u}$ - pop. unserved by WCS (nr. of inhab.)

Ig -per capita generation of household waste $(0.8 \mathrm{~kg}$.inhab/day - an average value for 2003, adding an annual increase of $0.8 \%$ ).

The next step is to calculate the share of $\mathrm{Q}_{\mathrm{wu}}$ from total $\mathrm{Q}_{\mathrm{HSw}}$ collected in the

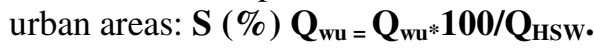

Tab. 4. Share of $\mathrm{Q}_{\mathrm{wu}}(\%)$ from total amounts of HSW collected

\begin{tabular}{|c|c|c|c|}
\hline$S Q_{w u}(\%)$ & $2004^{*}$ & 2007 & 2010 \\
\hline Piatra Neamţ & 14 & 34.39 & 35.9 \\
\hline Roman & 13.2 & 5.05 & 26.39 \\
\hline Tirgu Neamţ & 9.68 & 28.07 & 72.41 \\
\hline Bicaz & 14.28 & 24.28 & 15.47 \\
\hline Roznov & 100 & 100 & 100 \\
\hline
\end{tabular}

*non reliable data

Urban population without access to WCS dispose the HSW on improper sites from surroundings, polluting the local environment and threatening human health. These situations prevailed in Roznov because of the lack of WCS during 20042010 and also in rural localities included in the administrative territorial units (ATU) of Piatra Neamt, Bicaz and Tg Neamt.

Tab. 5 PAM of municipal waste management system in 2004 (pre-accession period)

\begin{tabular}{|c|c|c|c|c|c|c|}
\hline City & WCS & SC & 2R & Landfilling & $\mathbf{Q}_{\text {wu }}$ & $\begin{array}{c}\text { Total } \\
\text { Score }\end{array}$ \\
\hline Piatra Neamt & 4 & 0 & 0 & 0 & 2 & $\mathbf{6}$ \\
\hline Roman & 6 & 0 & 0 & 0 & 2 & $\mathbf{8}$ \\
\hline Tg Neamț & 0 & 0 & 0 & 0 & 2 & $\mathbf{2}$ \\
\hline Bicaz & 4 & 0 & 0 & 0 & 2 & $\mathbf{6}$ \\
\hline Roznov & 0 & 0 & 0 & 0 & 0 & $\mathbf{0}$ \\
\hline
\end{tabular}

On the other side, the data concerning waste flows is questionable because they are volumetrically estimated $\left(\mathrm{m}^{3}\right)$ and transformed in tons, and only Piatra Neamt has a weighting system since 2007. In this context, volumetric estimates of $\mathrm{Q}_{\text {wu }}$ are overestimated in most cities, reflecting the low share of $\mathrm{Q}_{\text {wu. }}$ in 2004. The last data are more reliable and outline the high share of $\mathrm{Q}_{\mathrm{wu}}(>20 \%)$. In this case no 
points will be added according to the assessment table. The extension of WCS is a basic condition for a sustainable waste management system.

Traditional municipal waste management purely based on mixed waste collection and landfilling prevailed for all towns in the county In this case, no urban locality has more than 10 points accumulated according to assessment grid.

Because the share of $\mathrm{Q}_{\mathrm{wu}}$ varies considerably in relation to the amounts of HSW (whose values in 2004 were overestimated by waste operators) we could not compute the evaluation grid for this indicator. In any case, municipal waste management systems in 2004 were rudimentary and also partially served the urban population. Furthermore, Roznov had no WCS during 2004-2010, and this fact led to uncontrolled disposal of household waste on surroundings.

Tab. 6 PAM of municipal waste management system in 2007

\begin{tabular}{|c|c|c|c|c|c|c|}
\hline City & WCS & SC & 2R & Landfilling & $\mathbf{Q}_{\text {wu }}$ & $\begin{array}{c}\text { Total } \\
\text { score }\end{array}$ \\
\hline Piatra Neamț & 4 & 4 & 2 & 2 & 0 & $\mathbf{1 2}$ \\
\hline Roman & 6 & 0 & 0 & 0 & 2 & $\mathbf{8}$ \\
\hline Tg Neamț & 0 & 0 & 0 & 0 & 0 & $\mathbf{0}$ \\
\hline Bicaz & 2 & 0 & 0 & 0 & 0 & $\mathbf{2}$ \\
\hline Roznov & 0 & 0 & 0 & 0 & 0 & $\mathbf{0}$ \\
\hline
\end{tabular}

Romania's EU accession year (2007) hasn't brought major changes to municipal waste management system, for Roman, Tg.Neamt, Bicaz and Roznov prevailing the same rudimentary performance (under 10 points). Again, the last indicator $\left(\mathrm{S} \% \mathrm{Q}_{\mathrm{wu}}\right)$ for Roman was not taken into account for the assessment grid due to overestimated volumetric data on HSW collected.

Piatra Neamţ has implemented since 2007 an integrated municipal solid waste management, providing separate collection points for waste streams (biodegradable, paper / cardboard, plastic / glass and residual), two bulky waste collection centers (furniture, WEEE, waste from construction and demolition) and also special containers for hazardous municipal waste. Near the sanitary landfill is also located the sorting and composting stations and the crush plant for C\&D fraction. Following the first year, the new system led to a significant increase of separate collection waste and also a positive trend for recycling vs landfilling, but the performance is still poor (12 points).

After three years the same rudimentary performance of municipal waste management systems prevails in Roman, Tg. Neamt, Bicaz and Roznov. However, there are some infrastructure improvements for selective waste collection in Roman, but the efficiency is low. In terms of $\mathrm{Q}_{\mathrm{wu}}$ indicator based on more reliable data of waste flows it could be achieved a weighting of this indicator from total 
HSW collected $(\mathrm{t} / \mathrm{yr})$. Thus, high values of this indicator for most towns ( $>20 \%)$ highlights that illegal dumping of waste is significant particularly in rural areas annexed to administrative territorial units of cities, these facts are also confirmed by field observations.

Tab. 7 PAM of municipal waste management system in 2010 (post-accession period)

\begin{tabular}{|l|c|c|c|c|c|c|}
\hline \multicolumn{1}{|c|}{ City } & WCS & SC & 2R & Landfilling & $\mathbf{Q}_{\text {wu }}$ & Total \\
\hline Piatra Neamt & 4 & 4 & 0 & 2 & 0 & $\mathbf{1 0}$ \\
\hline Roman & 8 & 0 & 0 & 0 & 0 & $\mathbf{8}$ \\
\hline Tg Neamt & 0 & 0 & 0 & 0 & 0 & $\mathbf{0}$ \\
\hline Bicaz & 6 & 0 & 0 & & 2 & $\mathbf{8}$ \\
\hline Roznov & 0 & 0 & 0 & 0 & 0 & $\mathbf{0}$ \\
\hline
\end{tabular}

Although the results of PAM applied to Piatra Neamţ were promising in 2007, it is noted a slight decrease due to a stagnant trend in terms of people's access to WCS and secondly due to a poor recycling and recovery of household waste collected. Full access to WCS, good practices of inhabitants regarding the correct separate collection and development of waste market for recyclable fractions are three key factors beside a modern infrastructure necessary for results improvement of PAM. Also, new waste management facilities were operational since 2011 in Târgu Neamţ, Bicaz and Roznov, contributing to an upward trend on this sector.

\section{Conclusions}

The background of traditional waste management system based on mixed waste collection, waste disposal in non-compliant landfills and illegal dumping prevails in most urban localities of Neamt County during 2004-2010, threatening the urban environment and human health. Only Piatra Neamţ has an modern waste management infrastructure system since 2007, but it is outlined that the performance is poor so far.

The role of local authorities to prepare the people for the transition from a traditional to a sustainable waste management system in a short period of time is essential and cannot stagnate, otherwise Romania will not be able to comply the objectives assumed to the EU in this priority area of environmental policies.

\section{References:}

Cifrian E., Galan,B., Andres,A., Javier R. Viguri (2012). Material flow indicators and carbon footprint for MSW management systems: Analysis and application at regional level, Cantabria, Spain

Desmond Margaret (2006), Municipal solid waste management in Ireland: Assessing for sustainability, Irish Geography, 39 (1), 22-33 
Karak T,. Bhagat R. M, Bhattacharyya, P. (2012) Municipal Solid Waste Generation, Composition, and Management: The World Scenario, Critical Reviews in Environmental Science and Technology, 42 (15), 1509-1630

Mihai F.C. , Apostol, L., (2012) Disparities in municipal waste management across EU27. A geographical approach, Present Environement and Sustainable Development, 6 (1), 169-180

Mihai, F.C., (2012) Geography of waste as a new approach in waste management study, Papers of "Dimitrie Cantemir" Geographical Seminar, 33, 39-46

Mihai, F.C., Lămășanu, A., Apostol, L., 2012, Regional disparities in urban population access to sanitation services. Case study: Romania, Mediterranean Journal of Social Sciences, Special issue, 3 (6), 273-279

Mihai, F.C., Ghiurca A.,Lamasanu,A., (2011) Estimation of urban waste generated and uncollected in Romania, Analele Universitati Oradea,Fascicula:Protectia Mediului, 17(2),719-724

Mihai, F.C., (2012) Population access to waste collection services: urban vs rural areas in Romania, Bulletin USAMV Agriculture, 69 (2) short com., 464-466

Passarini,F.,Vassura,I., Monti, F., Morselli. L., Villani, B., (2011) Indicators of waste management efficiency related to different territorial conditions, Waste Management, 31 ,pp. 785-792 